\title{
REVIEW
}

\section{Non-invasive prenatal diagnosis of aneuploidies: new technologies and clinical applications}

\author{
Elisavet A Papageorgiou ${ }^{1,2}$ and Philippos C Patsalis ${ }^{1 *}$
}

\begin{abstract}
Non-invasive prenatal diagnosis (NIPD) has substantial medical importance as it targets the development of safer and more effective methods to avoid the risk of fetal loss associated with currently used invasive methods. Several approaches have been demonstrated as being proof-of concept for NIPD of chromosomal aneuploidies. These approaches include cell-based and cell-free detection methods, involving the investigation of fetal cells in the maternal circulation, formaldehyde treatment of maternal plasma, DNA methylation studies using sodium bisulfite or restriction enzymes, protein-based studies, identification of fetal-specific mRNAs and digital polymerase chain reaction (PCR) approaches, and recently next-generation sequencing and methylated DNA immunoprecipitation real-time quantitative PCR-based approaches. Although all these NIPD methods have both advantages and limitations, some are moving closer to clinical implementation. Biotechnology companies dedicated to the development of NIPD tests such as the sequencingor methylation-based approaches are finalizing large clinical trials. It is expected that these new technologies will facilitate safer, more sensitive and accurate prenatal diagnostic tests in the near future. In this review, we highlight the most recent advances in methods for NIPD of aneuploidies, and we discuss their future implications in clinical practice.
\end{abstract}

Keywords fetal DNA, fetal-specific methylation, next generation sequencing, NIPD clinical implementation, non-invasive prenatal diagnosis

*Correspondence: patsalis@cing.ac.cy

'The Cyprus Institute of Neurology and Genetics, PO Box 23462, 1683, Nicosia, Cyprus

Full list of author information is available at the end of the article

\section{Prenatal diagnosis of aneuploidies}

Prenatal diagnosis was introduced in the early 1970s with the primary aim of diagnosing aneuploidies such as trisomy 21 (Down syndrome), trisomy 18 (Edwards syndrome) and trisomy 13 (Patau syndrome), as well as aneuploidies related to $\mathrm{X}$ and $\mathrm{Y}$ chromosomes (for example, Klinefelter syndrome, trisomy $\mathrm{X}$ and Turner syndrome) [1-3]. The majority of cases with aneuploidy result in termination of the developing fetus [4] and aneuploidy is responsible for at least 35\% of miscarriages [5]. Nevertheless, there can be cases of live birth, with the most common being trisomies 21, 18 and 13 [4]. The highest survival rate occurs with trisomy 21, which affects 1 in 800 births, whereas trisomy 18 affects 1 in 6,000 births, and trisomy 13 affects 1 in 10,000 births [6]. Prenatal diagnosis has been of great importance since it provides parents with the choice to abort a fetus with the diagnosed condition or to prepare psychologically, socially, financially and medically for a baby with a health problem or disability, or for the likelihood of a stillbirth.

Prenatal diagnosis is achieved through the collection and testing of fetal material during the first, second or third trimester of pregnancy. The most common methods currently used for sampling fetal material are chorionic villi sampling (CVS) during the first trimester and amniocentesis during the second trimester $[7,8]$. The diagnostic accuracy of these methods is estimated to be 98 to $99 \%$ [9]. However, both sampling procedures are invasive, and independent studies indicate that they are associated with a significant risk of fetal loss, which occurs in 0.5 to $1 \%$ of all tested cases $[1,10]$. The risk of fetal loss could be even higher, especially during CVS, if the doctor who performs the sampling procedure is not highly experienced [11]. For this reason invasive prenatal diagnosis tests are currently performed only in high-risk pregnancies or in pregnancies with increased maternal age and/or family history of having a child with an inherited disease.

The limitations of these invasive methods have led to research efforts towards the development and implementation of non-invasive prenatal diagnostic (NIPD) methods for common aneuploidies and other fetal chromosomal abnormalities. NIPD has been shown to have no associated risk of miscarriage and could therefore be 
implemented for any pregnant woman, irrespective of age or risk of having an affected child [9].

NIPD methods that have been described to date are divided into two categories: cell-based and cell-free approaches, with the second being the most commonly used. The discovery of free fetal DNA (ffDNA) in the maternal circulation during pregnancy [12] was probably the most important step in opening the way towards the development of NIPD approaches. ffDNA has been used successfully for the determination of fetal sex and fetal Rhesus D status in maternal plasma [13,14], and these methods are currently applied as routine tests in a number of diagnostic laboratories worldwide. However, direct analysis of the limited amount of ffDNA (3 to 6\%) [15] in the presence of an excess of maternal DNA is a great challenge for NIPD assessment of fetal aneuploidies. Recent studies suggest that fetal DNA accounts for 10 to $20 \%$ of total DNA in the maternal circulation [16]. In aneuploidies, one of the chromosomes is present with additional or fewer copies. For example, in trisomy 21, three copies of chromosome 21 are present instead of two. Therefore, the ability to distinguish normal cases from trisomy 21 cases would depend on the ability to detect the extra copy of chromosome 21 . The relatively high levels of maternal DNA in the maternal circulation compared with the limited amount of fetal DNA further complicate quantification.

Over the past decade a large number of different methods have been applied to enable discrimination of ffDNA from circulating maternal DNA or ffDNA enrichment $[17,18]$. These include DNA-based approaches that directly target ffDNA sequences, such as sequencing approaches $[19,20]$. Additional studies have focused on the development of epigenetic approaches, with the majority of these investigating the methylation status of fetal DNA using either sodium bisulfite DNA treatment [21], methylation-sensitive restriction enzymes [22] or antibodies specific to the 5-methylcytosine residues of CpG dinucleotides in the genome [23]. Alternative approaches have targeted fetal-specific mRNA [24] or have focused on the investigation of fetal-specific proteins [25].

In this review, we discuss methods for NIPD of aneuploidies, highlighting the most recent advances, their advantages and disadvantages, and their future use in clinical practice.

\section{Developments in aneuploidy detection Cell-based detection methods}

NIPD was initially attempted through the isolation and investigation of intact fetal cells from the maternal circulation during pregnancy. A number of different fetal cell types have been found in maternal peripheral blood, including fetal trophoblasts, leukocytes and nucleated red blood cells (NRBCs). Trophoblast enrichment and isolation is hindered by the lack of placental-specific antibodies as well as the presence of multinucleated morphology $[26,27]$. Leukocytes may persist from previous pregnancies, which complicates their evaluation in a subsequent pregnancy. Furthermore, leukocytes lack unique cell markers that could be used to discriminate fetal from maternal leukocytes [28]. However, NRBCs have a short half-life of 25 to 35 days and are therefore unlikely to persist from previous pregnancies [29]. Moreover, they have unique cell morphology and a complete chromosomal complement. Consequently, the majority of studies based on fetal cell recovery in maternal circulation have focused on the investigation of NRBCs [30,31].

Techniques such as fluorescence in situ hybridization (FISH) and polymerase chain reaction (PCR) have shown that there is an average of one fetal NRBC per milliliter of maternal peripheral blood, with a maximum of six fetal cells per milliliter of maternal peripheral blood [32,33]. Due to this limited number of fetal NRBCs, both FISHand PCR-based approaches have difficulties in isolating and investigating these cells. Using FISH, the majority of NRBCs are identified as maternal and only a small proportion (if any) are identified as being of fetal origin $[30,31]$. Single-cell PCR approaches have shown that at least $50 \%$ of the NRBCs are of maternal origin [34]. In addition, the majority of these cells undergo apoptosis, which leads to unstable and fragmented DNA that is not suitable for molecular cytogenetic analysis [35,36]. PCR analysis of these cells is also associated with allele dropout (failure to amplify or detect an allele). To overcome these difficulties, a higher number of fetal cells would need to be analyzed (for example, five to six fetal cells) [37].

\section{Fetal cell enrichment strategies}

Enrichment to increase the number of fetal cells isolated from the maternal circulation has been of great importance in reducing the complexity of evaluating fetal cells. The first step involves Ficoll-Paque or Percollgradient density centrifugation to remove mature red blood cells and granulocytes, leaving peripheral mononuclear cells [34,38]. Further enrichment is usually achieved using methods such as fluorescence-activated cell sorting (FACS) [31,39], magnetic-activated cell sorting (MACS) [40,41] or charge flow separation [42]. The general principle of these methods is the separation and isolation of fetal cells from maternal cells using monoclonal antibodies that target fetal-specific cell surface antigens. The first monoclonal antibody used for enrichment of fetal cells was directed against CD71, the transferrin receptor [30]; however, purity after FACS was low. An improvement was later made by using MACS depletion of anti-CD45 prior to selection of CD71-positive 
cells [43]. However, the methods used so far have had low recovery rates.

\section{Detection of aneuploidies}

An early prospective multi-center study to evaluate the utility of fetal NRBCs for NIPD of aneuploidies was initiated in 1994. The study, which was completed after 5 years and included 2,744 maternal samples, demonstrated that only $41.1 \%$ of male euploid cases could be identified, whereas the success rate was higher in aneuploid cases $(74.4 \%)$, indicating that fetal cells are more abundant in aneuploid pregnancies and therefore more easily detected [44]. Independent studies using PCR methods have confirmed these findings, especially in trisomy 21 cases, and have reported sixfold higher numbers of fetal cells in maternal blood in trisomy 21 cases compared with normal cases [45].

Although the use of NRBCs was initially promising for prenatal diagnosis, their extremely small number in the maternal circulation, as well as the fact that the vast majority are of parental origin, has not allowed the successful implementation of fetal cell-based approaches [45-47]. Another approach is the investigation of intracellular fetal-specific proteins; however, there is not much evidence yet to support this method [48].

An alternative source of intact fetal cells is the distal endocervical canal. Fetal cells released into the uterine cavity during early pregnancy are a potential source of material for NIPD [49], and are most probably extravillous trophoblasts [50,51]. In a study of 28 normal pregnancies and five trisomy 21 cases at 12 to 13 weeks of gestation, abnormal fetal cells were identified in all abnormal pregnancies, and one abnormal cell was detected in a normal pregnancy using dual FISH labeling and automated microscopy [52]. Nevertheless, larger-scale validation studies are required to evaluate the sensitivity and specificity of this approach for NIPD of aneuploidies.

It is evident that once a highly sensitive method for isolating intact fetal cells is developed, the advantages for NIPD would be great. Intact fetal cells contain the complete fetal genome, which could be investigated using high throughput methods such as microarray- and sequencing-based technologies for screening and diagnosis of aneuploidies as well as other genomic disorders.

\section{Cell-free detection methods}

The discovery of free nucleic acids in the circulation of adults in 1948 [53] has been of great importance in the field of NIPD. Based on this observation, in 1997 Lo and colleagues described for the first time the presence of cell-free fetal DNA (cffDNA) in maternal peripheral blood during pregnancy [12]. Subsequent studies have shown that cffDNA is detectable from the first trimester of pregnancy in maternal plasma at an abundance of 3\% of total plasma DNA. This value increases during pregnancy, reaching $6 \%$ towards the end of the pregnancy $[15,54,55]$, although more recent studies have demonstrated a range of 10 to $20 \%$ of fetal DNA [16]. The studies that refer to a higher percentage of fetal DNA are more recent and they have been using more advanced technologies (digital PCR) compared to previous studies that have used real time quantitative PCR (qPCR) technologies. The first non-invasive diagnostic efforts aimed to identify Y chromosomal regions and thereby determine fetal sex, which would facilitate the early detection of hereditary X-linked disorders [56]. In addition, the use of DNA markers such as single nucleotide polymorphisms (SNPs) has allowed the detection of fetal genetic abnormalities. One such example is the detection of paternally inherited SNPs located in the $\beta$-globin locus for NIPD of $\beta$-thalassemia $[57,58]$. Furthermore, the application of PCR technology in combination with mass spectrometry (MS) has allowed the detection of fetal monogenic mutations present in the maternal circulation [57-63]. One such application was the use of the MassARRAY system, a matrix-assisted laser desorption ionization time-of-flight MS system designed for the detection of primer-extended PCR products [62,64]. The MassARRAY system has been used successfully for the reliable exclusion of $\beta$-thalassemia mutations in maternal plasma.

Nevertheless, the development of NIPD for aneuploidies remains the greatest challenge, and the primary target has been trisomy 21, the most common aneuploidy [6]. One of the first difficulties to overcome was the limited amount of cffDNA in the maternal circulation (3 to 6\% [15] or 10 to $20 \%$ based on recent studies [16]). For this reason, the primary focus has been on the development of methods for the enrichment of cffDNA to enable accurate quantification of copy number changes that are associated with fetal aneuploidies.

\section{DNA detection methods}

Initial attempts took advantage of the small size of cffDNA fragments, which were estimated to be smaller than $300 \mathrm{bp}$, whereas maternal DNA fragments are much bigger [17]. This discovery spurred the development of methods for the isolation of small DNA fragments present in the maternal circulation [65] - for example, by agarose gel electrophoresis of plasma samples followed by size-fractionated fragment analysis by real-time qPCR. Highly polymorphic microsatellite markers on chromosome 21 were used to discriminate paternally derived and maternally derived fetal genetic traits. However, these methods could not be used for the development of NIPD for aneuploidies since they are laborious and susceptible to contamination from other sources of nucleic acids [66]. 
An alternative approach for cffDNA enrichment and development of NIPD for trisomy 21 was the treatment of maternal peripheral blood with formaldehyde. The theory behind this was that stabilization of maternal white blood cells using formaldehyde would lead to reduced maternal cell lysis, and therefore less maternal DNA would be released into the maternal plasma $[67,68]$, leading to reduced maternal background and therefore indirect enrichment of cffDNA in maternal plasma. This approach was performed in 60 pregnancies including three trisomy 21 cases, and 56 of 57 normal cases and two of the three trisomy 21 cases were correctly classified. Although the initial findings of this approach were promising, they were not reproducible by independent research groups (Table 1) [69,70].

\section{DNA methylation-based methods}

A different approach adopted by a large number of groups has been the investigation of epigenetic differences between fetal DNA and maternal DNA. Methylation is one of the most common epigenetic mechanisms under investigation, especially in cancer research $[71,72]$. The identification of tumor-specific DNA methylation patterns in the plasma of cancer patients [73-75] has raised the possibility of identifying fetal-specific methylation patterns in the maternal circulation. The aim of this approach is the identification and selection of fetalspecific markers that have the potential to be developed into NIPD diagnostic markers. One of the most widely used methods for investigating DNA methylation patterns is treatment with sodium bisulfite $\left(\mathrm{NaHSO}_{3}\right)$, and this has been used by the majority of methylation-based studies for NIPD. This technique relies on the conversion of nonmethylated cytosine to uracil, which allows the discrimination of methylated from non-methylated DNA sequences. The study of both methylated and non-methylated sequences is achieved by the design of primers that target either the methylated or non-methylated regions followed by methylation-specific PCR [76].

In 2002, Poon and colleagues demonstrated for the first time the presence of DNA methylation differences between maternal and fetal DNA [18]. Three years later, the same team reported the first gene to be shown to have differential methylation patterns between maternal and fetal DNA: SERPINB5 (encoding serine protease inhibitor B5), located in chromosomal region 18q [21]. To achieve this, sodium bisulfite conversion of DNA was applied in combination with methylation-specific PCR using placental (fetal) DNA samples and DNA samples from non-pregnant women. The promoter region of SERPINB5 was shown to be hypomethylated in fetal DNA and hypermethylated in non-pregnant female DNA. Furthermore, the same group detected these hypomethylated DNA sequences in cell-free DNA extracted from maternal plasma during pregnancy, indicating the presence of cffDNA in the maternal circulation.

Alternative approaches have used sodium bisulfiteconverted DNA in combination with digital PCR and/or MS analysis for the successful quantification of cffDNA in maternal plasma [77]. Furthermore, studies have shown that the combination of sodium bisulfite DNA treatment with the identification of SNPs within differentially methylated regions (DMRs) can facilitate cffDNA quantification [22,78-80]. Specifically, this technique requires the presence of at least one SNP that is homozygous in the mother and heterozygous in the fetus, and therefore is only possible in cases with such informative SNPs. However, the successful and full conversion of non-methylated cytosine to uracil is rarely achieved. Moreover, DNA degradation occurs after treatment with sodium bisulfite [81] and further complicates the quantification of extremely low amounts of cffDNA (Table 1).

An additional methylation-based approach is the use of methylation-sensitive restriction enzymes, which can either be methylation-specific (recognize and cut specific methylated sites) or non-methylation-specific (recognize and cut specific unmethylated sites). The use of nonmethylation-specific restriction enzymes [82] can result in enrichment of methylated genomic regions and the decomposition of non-methylated DNA. Therefore, when using such enzymes to treat maternal plasma, the sequences that are hypermethylated in fetal DNA are enriched. A significant number of studies have been based on the use of such restriction enzymes $[22,77,79]$. However, this approach is limited by the number of regions that are suitable for testing, since the possibility of having a methylation-sensitive restriction site within the feto-maternal DMRs of interest is rare (Table 1) $[18,22,79,83-85]$.In these conventional methylation-based approaches, a large number of feto-maternal methylation differences have been detected, primarily on chromosome $21[22,23,77]$. Although these methods are costeffective and do not require prior knowledge or expensive infrastructure, they can only be applied to $\mathrm{CpG}$ islands and promoter regions, which cover only a small fraction of the genome.

\section{Protein detection methods}

In addition to approaches aimed at detecting fetalspecific nucleic acids in the maternal circulation, efforts have been made to detect fetal-specific proteins in maternal plasma. The purpose of this approach was the discrimination between normal and abnormal pregnancies based on protein quantification. However, the presence of high levels of maternal proteins in maternal plasma makes the quantification of fetal-specific proteins challenging. Therefore, studies have now shifted to 
Table 1. Advantages and disadvantages of different NIPD approaches

\begin{tabular}{|c|c|c|c|c|c|c|}
\hline Technology & $\begin{array}{l}\text { Sensitivity/specificity } \\
(\%)\end{array}$ & Cost & Complexity & $\begin{array}{l}\text { Reproduced by } \\
\text { other groups } s^{\mathrm{a}}\end{array}$ & Advantages & $\begin{array}{l}\text { Technical and clinical } \\
\text { challenges }\end{array}$ \\
\hline $\begin{array}{l}\text { Formaldehyde treatment } \\
{[67,68]}\end{array}$ & $\begin{array}{l}98.2 \% \text { sensitivity } \\
66.6 \% \text { specificity }\end{array}$ & Low & Simple & No & $\begin{array}{l}\text { Indirect enrichment } \\
\text { of fetal DNA }\end{array}$ & $\begin{array}{l}\text { Requires a large number of } \\
\text { informative SNPs }\end{array}$ \\
\hline $\begin{array}{l}\text { DNA methylation studies } \\
\text { using sodium bisulfite } \\
{[21,78-80]}\end{array}$ & $\begin{array}{l}\text { Small independent } \\
\text { studies }\end{array}$ & Low & Simple & Not tested & $\begin{array}{l}\text { Direct enrichment of } \\
\text { fetal DNA }\end{array}$ & $\begin{array}{l}\text { DNA degradation, full conversion } \\
\text { is rarely achieved }\end{array}$ \\
\hline $\begin{array}{l}\text { DNA methylation studies } \\
\text { using restriction enzymes } \\
{[22,77,79]}\end{array}$ & $\begin{array}{l}\text { Small independent } \\
\text { studies }\end{array}$ & Low & Simple & Not tested & $\begin{array}{l}\text { Indirect enrichment } \\
\text { of fetal DNA }\end{array}$ & $\begin{array}{l}\text { Limited to the investigation of } \\
\text { regions with restriction sites }\end{array}$ \\
\hline $\begin{array}{l}\text { Protein-based studies } \\
{[25,87]}\end{array}$ & $\begin{array}{l}\text { Small independent } \\
\text { studies }\end{array}$ & Low & Simple & Not tested & $\begin{array}{l}\text { Direct discrimination } \\
\text { of fetal proteins }\end{array}$ & $\begin{array}{l}\text { Requires accurate quantification } \\
\text { to distinguish normal from } \\
\text { abnormal pregnancies }\end{array}$ \\
\hline $\begin{array}{l}\text { Next-generation } \\
\text { sequencing }[19,20,89,91,95]\end{array}$ & $\begin{array}{l}99.2 \text { to } 100 \% \text { sensitivity } \\
97.9 \text { to } 99.7 \% \text { specificity }\end{array}$ & High & Complex & Yes & Reliable & $\begin{array}{l}\text { Time consuming (more than } \\
\text { one week to obtain the result), } \\
\text { laborious, requires technical } \\
\text { expertise, requires expensive } \\
\text { equipment and infrastructure }\end{array}$ \\
\hline $\begin{array}{l}\text { MeDIP real time qPCR- } \\
\text { based approach }[98,99]\end{array}$ & $\begin{array}{l}100 \% \text { sensitivity } \\
100 \% \text { specificity }\end{array}$ & Low & Simple & Not tested & $\begin{array}{l}\text { Results obtained } \\
\text { within } 3 \text { to } 4 \text { days }\end{array}$ & $\begin{array}{l}\text { Requires } 100 \% \text { antibody } \\
\text { performance, requires extensive } \\
\text { quality control of reagents prior } \\
\text { to use }\end{array}$ \\
\hline $\begin{array}{l}\text { Identification of } \\
\text { fetal-specific mRNAs } \\
{[104,106,108,109]}\end{array}$ & $\begin{array}{l}100 \% \text { sensitivity } \\
89.7 \% \text { specificity }\end{array}$ & Low & Simple & Not tested & $\begin{array}{l}\text { Direct discrimination } \\
\text { of fetal RNA from } \\
\text { maternal RNA }\end{array}$ & $\begin{array}{l}\text { Requires a large number of } \\
\text { informative SNPs, limited by } \\
\text { mRNA stability }\end{array}$ \\
\hline $\begin{array}{l}\text { Digital PCR-based approach } \\
{[110,111]}\end{array}$ & Proof-of-principle & High & Complex & Not tested & $\begin{array}{l}\text { Accurate } \\
\text { quantification of DNA } \\
\text { molecules }\end{array}$ & $\begin{array}{l}\text { Requires technical expertise, } \\
\text { simplification is achieved by the } \\
\text { use of microfluidic devices, which } \\
\text { are expensive and not widely } \\
\text { available }\end{array}$ \\
\hline $\begin{array}{l}\text { Epigenetic-genetic } \\
\text { chromosome-dosage } \\
\text { approach }[78,79]\end{array}$ & $\begin{array}{l}96.9 \% \text { sensitivity } \\
92.8 \% \text { specificity }\end{array}$ & High & Complex & Not tested & Use of digital PCR & $\begin{array}{l}\text { Requires a large number of } \\
\text { informative SNPs, simplification } \\
\text { is achieved by the use of } \\
\text { microfluidic devices, which } \\
\text { are expensive and not widely } \\
\text { available }\end{array}$ \\
\hline
\end{tabular}

${ }^{a}{ }^{\prime} \mathrm{No}^{\prime}$ refers to the presence of published literature indicating failure to reproduce the results by independent groups;'Not tested' refers to the absence of published literature indicating reproduction of the results by independent groups. MeDIP, methylated DNA immunoprecipitation; PCR, polymerase chain reaction; qPCR, quantitative polymerase chain reaction; SNP, single nucleotide polymorphism.

implement methods to reduce the ratio of maternal proteins relative to fetal proteins [86]. Following indirect enrichment of fetal proteins, techniques such as twodimensional gel electrophoresis enable the separation and detection of rare proteins of fetal origin in maternal plasma [25,87]. However, there is at present no convincing evidence of a commonly identified fetal-specific protein in maternal plasma, which is probably due to the high complexity of the plasma proteome, which derives from every tissue of the body.

A new era of non-invasive prenatal diagnosis for aneuploidies To address the limitations of previous applications, a number of revolutionary and novel approaches have been developed (Table 1).

\section{Next-generation sequencing approaches}

The implementation of next-generation sequencing (NGS) technologies in the development of NIPD of aneuploidies has revolutionized the field. In 2008, two independent groups demonstrated that NIPD of trisomy 21 could be achieved using next-generation massively parallel shotgun sequencing (MPSS) of maternal plasma $[19,20]$. Follow-up studies have demonstrated that the sensitivity of the approach is restricted by the number of sequencing reads [88].

Large-scale validation studies were then performed by research groups and biotechnology companies. One of the first studies performed included 753 pregnancies, of which 86 included fetuses with trisomy 21 [89]. However, $7.1 \%$ of the samples were excluded from the analysis 
(Table 2). Nevertheless, the samples tested demonstrated $100 \%$ sensitivity and $97.9 \%$ specificity of the approach. An independent study performed by a biotechnology company prospectively tested 480 pregnancies, of which 39 were in women carrying a fetus with trisomy 21 [90]. In this study the sensitivity and specificity were calculated to be $100 \%$ and $99.7 \%$, respectively. However, the authors' exclusion criteria meant that $6.4 \%$ of the samples were excluded from testing and/or analysis (Table 2). The same biotechnology company has recently performed a larger scale international clinical study to validate their laboratory-developed test (LDT). The study included 4,664 pregnancies of which only 1,696 were analyzed. The sample exclusion was based on a number of criteria (Table 2). Among the selected samples, 212 were obtained from trisomy 21 pregnancies. The sensitivity and specificity of the test were calculated to be $99.2 \%$ and $98.6 \%$, respectively [91]. In addition, several pilot studies have shown the ability of MPSS to detect trisomy 18 and trisomy 13 non-invasively, although with more variable results [92-94].

An alternative NGS approach was adopted by a different biotechnology company. The study was performed with 298 pregnancies collected from first, second and third trimester pregnancies, and included 39 trisomy 21 cases and seven trisomy 18 cases [95]. The samples were analyzed using a novel, highly multiplexed assay termed digital analysis of selected regions (DANSR). Cell-free DNA from maternal blood samples was analyzed using DANSR assays for loci on chromosomes 21 and 18. This study showed correct classification of all abnormal cases tested (Table 2). Furthermore, an independent research group has described a new approach based on single molecule DNA sequencing of cell-free DNA in maternal plasma [96]. In this study, 20 maternal plasma samples were tested, of which 11 were obtained from trisomy 21 pregnancies. The samples were obtained at 9 to 16 weeks of gestation. The results indicated that all cases were correctly classified. Furthermore, trisomy 21 fetuses could be more clearly distinguished from euploid fetuses compared with the other sequencing approaches (Table 2). In addition, the proof of concept for NIPD of fetal microdeletion syndromes via sequencing has recently been described [97].

\section{Methylated DNA immunoprecipitation real-time qPCR-based approach}

An alternative approach for the development of NIPD of aneuploidies has recently been described by our group. The approach is based on the application of methylated DNA immunoprecipitation (MeDIP), which takes advantage of the methylation differences that are present in maternal and fetal DNA. MeDIP application allows enrichment of fetal-specific hypermethylated regions by using an antibody that targets the 5-methylcytosine residues of CG dinucleotides [71,84]. In 2009, our team applied the MeDIP approach in combination with highresolution microarrays and identified a large number of feto-maternal DMRs on chromosomes that are associated with the development of the most common fetal aneuploidies (chromosomes 13, 18, 21, X and Y) [98].

NIPD of trisomy 21 was then achieved by testing a small number of selected DMRs using the MeDIP approach in combination with real time qPCR. The study was performed with 80 pregnancies, of which 34 were obtained from women carrying a trisomy 21 fetus. The pregnancies tested were in the range of 10 to 13 weeks of gestation. Correct diagnosis was obtained for all normal and abnormal cases, demonstrating $100 \%$ sensitivity and specificity of the approach (Tables 1 and 2) [99]. Subsequently, a large-scale clinical trial including about 700 cases is currently in progress.

\section{mRNA detection methods}

An alternative approach with the potential to be developed into an NIPD test for Down syndrome was based on the identification of fetal-specific mRNA in the maternal circulation during pregnancy. The primary aim was the identification of mRNAs that are actively transcribed only in the fetus and are released into the maternal circulation. The presence of fetal-specific mRNA in the maternal circulation was first described in 2000 [100]. Subsequent studies have investigated the stability of mRNA in maternal plasma [101-103]. In addition, one of the most important discoveries in this area is that the majority of mRNA molecules in the maternal circulation derive from the placenta [24]. Lo and colleagues successfully identified mRNA molecules that could be used for NIPD [104,105]. A large panel of fetal-specific mRNAs, actively transcribed only in the fetus but not in the mother, was identified. Subsequent studies showed that fetal-specific mRNA of genes located on chromosome 21 can be detected in maternal plasma $[106,107]$. One such gene is PLAC4 (encoding placenta-specific 4 protein, and located on chromosome 21), which is expressed in the placenta and is specific for the fetus in maternal plasma [106]. PLAC4 mRNA was used to develop NIPD for trisomy 21 using a so-called RNA-SNP strategy using MS. In this approach, informative SNPs (heterozygous in the fetus and homozygous in the mother) located in PLAC4 mRNA needed to be identified and used for NIPD of trisomy 21 [106]. This study was performed in 10 trisomy 21 cases and the diagnostic sensitivity and specificity of the approach were calculated to be $96.5 \%$ and $90 \%$, respectively. An improvement of the diagnostic efficiency was observed in a follow-up study performed by the same group. The study included 153 pregnancies in the first trimester including normal 
Table 2. Comparison of clinical validation studies performed for the NIPD of aneuploidies

\begin{tabular}{|c|c|c|c|c|}
\hline NIPD clinical study & Groups tested & Exclusion criteria & $\begin{array}{l}\text { Excluded } \\
\text { cases (\%) }\end{array}$ & $\begin{array}{l}\text { Clinical } \\
\text { findings: } \\
\text { sensitivity/ } \\
\text { specificity (\%) }\end{array}$ \\
\hline NGS study [89] & $\begin{array}{l}667 \text { normal } \\
86 \text { trisomy } 21\end{array}$ & $\begin{array}{l}\text { Insufficient sample quality (for example, amount of sample) } \\
\text { Failed quality control of sequencing (failed DNA extraction, } \\
\text { library construction or sequencing) }\end{array}$ & 7.1 & 100/97.9 \\
\hline NGS study [90] & $\begin{array}{l}441 \text { normal } \\
39 \text { trisomy } 21\end{array}$ & Insufficient sample quality (fetal fraction, total DNA) & 6.4 & 100/99.7 \\
\hline NGS study [91] & $\begin{array}{l}4,452 \text { normal } \\
221 \text { trisomy } 21\end{array}$ & $\begin{array}{l}\text { Sample not adequate (sample volume, long processing } \\
\text { time, poor sample quality) }\end{array}$ & 63.6 & $99.2 / 98.6$ \\
\hline $\begin{array}{l}\text { NGS study } \\
\text { (DANSR approach) [95] }\end{array}$ & $\begin{array}{l}252 \text { normal } \\
39 \text { trisomy } 21 \\
7 \text { trisomy } 18\end{array}$ & No exclusion criteria were mentioned & 0 & $100 / 100$ \\
\hline $\begin{array}{l}\text { NGS study } \\
\text { (single molecule DNA sequencing) } \\
{[96]}\end{array}$ & $\begin{array}{l}9 \text { normal } \\
11 \text { trisomy } 21\end{array}$ & $\begin{array}{l}\text { Insufficient sample quality (for example, fetal fraction) } \\
\text { Failed quality control of sequencing (for example, library } \\
\text { concentration) }\end{array}$ & 5 & $100 / 100$ \\
\hline $\begin{array}{l}\text { MeDIP real time qPCR-based } \\
\text { approach [99] }\end{array}$ & $\begin{array}{l}46 \text { normal } \\
34 \text { trisomy } 21\end{array}$ & No exclusion criteria were mentioned & 0 & $100 / 100$ \\
\hline $\begin{array}{l}\text { mRNA-based approach for trisomy } \\
21[108]\end{array}$ & $\begin{array}{l}137 \text { normal } \\
16 \text { trisomy } 21\end{array}$ & Cases with no informative SNP & 59.49 & $100 / 89.7$ \\
\hline $\begin{array}{l}\text { Epigenetic-genetic chromosome- } \\
\text { dosage approach [79] }\end{array}$ & $\begin{array}{l}24 \text { normal } \\
5 \text { trisomy } 21 \\
\text { (all pregnancies } \\
\text { with male fetuses) }\end{array}$ & Pregnancies with female fetuses & 0 & $95.8 / 100$ \\
\hline $\begin{array}{l}\text { Epigenetic-genetic chromosome- } \\
\text { dosage approach [78] }\end{array}$ & $\begin{array}{l}33 \text { normal } \\
14 \text { trisomy } 21\end{array}$ & Cases with no informative SNP & 0 & $96.9 / 92.8$ \\
\hline
\end{tabular}

and trisomy 21 cases. The results demonstrated 100\% sensitivity and $89.7 \%$ specificity [108]. This approach has also been applied in pregnancies with trisomy 18 (Table 1) [109].

\section{Digital PCR-based approach}

Digital PCR has been used for fetal DNA quantification by direct analysis of DNA extracted from maternal plasma. The proof-of principle of the approach has been described by two independent groups that used placental DNA to estimate the percentages of fetal DNA present in the maternal circulation [110,111]. Digital PCR differs from other quantitative approaches such as real-time PCR as it allows the reaction to proceed to its plateau instead of the exponential phase of the PCR reaction. The interpretation of the digital PCR result is a 'yes/no', which corresponds to the presence or absence of input template [112]. Two different approaches have been developed, the digital RNA-SNP strategy and the digital relative chromosome dosage (RCD) approach. The former strategy involves the determination of the allele imbalance of a SNP in fetal-specific PLAC4 mRNA, whereas in digital RCD the total copy number of chromosome 21 of a sample is compared with the total copy number of a reference chromosome (overrepresentation of chromosome 21 would indicate trisomy 21) [110].

\section{Epigenetic-genetic chromosome-dosage approach}

An alternative novel approach towards NIPD of chromosomal aneuplodies involves the combination of epigenetic and genetic markers of fetal origin present in maternal plasma. The group who investigated this approach identified a number of DMRs between fetal and maternal DNA using sodium bisulfite conversion. They then selected the fetal-specific hypermethylated marker HLCS (the gene encoding holocarboxylase synthetase) located on chromosome 21, and a fetal-specific marker located on chromosome Y (encoding zinc finger protein, Y-linked, $Z F Y$ ). The RCD approach was followed using digital PCR by comparing the dosage of the epigenetic marker HLCS with the copy numbers of $Z F Y$. The results obtained from 24 normal cases and five trisomy 21 cases have shown that all but one normal case were correctly classified [79]. Improvements to the above approach presented by the same group included the development of a new assay using an autosomal marker on chromosome 14 instead of 
$Z F Y$ as the genetic marker for comparison [78]. The method was validated in 33 normal cases and 14 trisomy 21 cases. One of the normal cases and one of the trisomy 21 cases were misclassified. The samples were collected at 12 to 18 weeks of gestation. Although the improved method was not restricted to male fetuses, it required the presence of informative SNPs within the genetic marker. Furthermore, this approach required the use of microfluidic digital PCR, which is expensive and not easily available to diagnostic laboratories (Table 1). This method also remains to be validated by independent studies.

\section{Challenges for clinical implementation}

The new era of NIPD for aneuploidies has opened new possibilities for the implementation of these technologies into clinical practice in the near future. Biotechnology companies that are partly or wholly dedicated to the development of NIPD tests have initiated large-scale clinical studies towards their implementation. In October 2011 one of the companies dedicated to the development of prenatal diagnostic tests announced the launch of its first NIPD test for trisomy 21, which is available in 20 major metropolitan regions across the United States (SEQUENOM Inc., San Diego, CA, USA) [113]. Their test (MaterniT21 test) is a LDT that analyzes circulating cell-free DNA extracted from a maternal blood sample using next-generation MPSS analysis. The test detects an increased representation of chromosome 21 material, which is associated with trisomy 21 [91].

A second biotechnology company (Aria Diagnostics Inc., San Jose, CA, USA) [114] has also developed an NGS-based approach [95]. According to the company, the approach requires one-tenth of the sequencing depth of the MPSS approach, as employed in the MaterniT21 test. In addition, 750 samples can be analyzed in one sequencing run, compared with the four to eight that have been tested with shotgun sequencing methods.

Another company (Verinata Health Inc., Redwood City, CA, USA) [115] has recently announced the launch of their NIPD test (Verifi prenatal test). The company has conducted a large validation study of 532 pregnancies including 89 trisomy 21 cases, 36 trisomy 18 cases, 14 trisomy 13 cases and 16 monosomy $\mathrm{X}$ cases using massively parallel sequencing. The results demonstrated $100 \%$ specificity and sensitivities of $100 \%, 97.2 \%, 78.6 \%$ and $93.8 \%$, respectively. The pregnancies tested were in the range of 8 to 22 weeks of gestation [116]. This study is the first to demonstrate the diagnostic efficiency of NGS in other aneuploidies in addition to trisomy 21 .

NGS approaches have the potential to be implemented in clinical practice not only for NIPD of trisomy 21 cases and other aneuploidies, but also for other chromosomal abnormalities, since they can be used for whole genome investigation in a single experiment. On the other hand, NGS approaches are time-consuming, laborious and technically challenging. Furthermore, they require a highly technological infrastructure, which is expensive and therefore not easily implemented in diagnostic laboratories (Table 1).

Another approach based on MeDIP real-time qPCR [99] is currently being developed as a commercially available test by another biotechnology company (NIPD Genetics Ltd, Nicosia, Cyprus) [117]. This is an antibodybased approach and relies on the sensitivity and specificity of the antibody to capture only methylated sites and not unmethylated sites. Therefore, it requires thorough quality control prior to use. Furthermore, this method remains to be validated by independent studies. Nevertheless, the approach is relatively fast compared with NGS approaches (Table 1).

An additional novel approach is the application of digital PCR for NIPD of aneuploidies. The proof-ofprinciple of this assay was described by two independent research groups, as mentioned earlier [110,111]. However, only one group has used this assay on maternal plasma samples for NIPD of trisomy 21 through the epigenetic-genetic chromosome-dosage approach [78,79]. The approach is being developed with a biotechnology company (SEQUENOM Inc.) [113]. The pilot study performed demonstrated that this approach has the potential to be implemented for NIPD of trisomy 21. Nevertheless, the results from a larger validation study still remain to be seen. Digital PCR technology is very promising since it allows accurate quantification of copy numbers in contrast to other quantification methods such as real-time PCR. However, it requires the development of microfluidic devices with several thousand reaction chambers in order to make it less laborious and time-consuming compared with manually performed conventional PCR. These devices are expensive and not available to the vast majority of diagnostic laboratories, and therefore this approach will not be easily implemented in clinical practice (Table 1).

The identification of fetal-specific mRNA molecules in maternal plasma and the development of non-invasive diagnostic assays has also been proposed. As discussed earlier, a team used the fetal-specific PLAC4 mRNA transcript for NIPD of trisomy 21 using MS [106,108]. Although this approach demonstrates high diagnostic efficiency, it can only be applied to pregnancies with informative SNPs within PLAC4 mRNA - this is rarely achieved since it requires a large panel of SNPs to be tested. Furthermore, this approach is laborious and limited by the stability of mRNA molecules, and requires specialized infrastructure that is not available to the majority of diagnostic laboratories. This method remains to be validated by independent studies (Table 1). 
The final selection of the test or tests that will likely be used for routine clinical diagnosis will rely on identifying the method that will provide the most convincing evidence of validity. Large-scale validation studies will be needed to provide a more accurate estimation of the diagnostic efficiency of each of the above methods. Furthermore, the selected test would need to be suitable for easy implementation in diagnostic laboratories worldwide. The test should require as little expensive equipment and reagents as possible, and should be as simple and as fast as possible since in the clinical diagnostic setting the speed of the test is one of the most critical factors, especially in prenatal diagnosis. Moreover, the selected test or tests would need to fulfill national or international criteria. Evaluation of the tests could, for example, be done using the quality assessment tool of diagnostic accuracy studies (QUADAS) guidelines [118], which consists of a 14-item checklist encompassing the most common sources of bias and variation observed in diagnostic accuracy.

\section{Conclusions and future directions}

NIPD is of substantial medical importance as it targets the development of safer and more effective methods to avoid the risk of fetal loss associated with currently used invasive methods. After 30 years of research, NIPD of aneuploidies is becoming a reality. Novel methods such as NGS approaches, the MeDIP real-time qPCR-based approach, mRNA detection methods and digital PCRbased methods have facilitated progress towards the implementation of NIPD of trisomy 21 in clinical practice. Nevertheless, current approaches have limitations and restrictions that hinder early and easy implementation. Such limitations are often associated with the cost of the infrastructure required for the assay to be applied, such as in the application of NGS approaches and digital PCR. NGS approaches and mRNA detection methods are also laborious and require prior knowledge. Furthermore, the successful implementation of the MeDIP real time qPCRbased approach depends on the quality and efficiency of the antibody used and requires thorough quality control before use.

So far, the most validated approach that has been tested in a large number of samples by independent groups is the NGS approach. This approach is expected to be the first to be introduced into clinical practice, since several biotechnology companies have already started providing services [113-115]. However, due to the limitations discussed earlier, such as the high cost and the time required, the method will require further improvements before it can be implemented in diagnostic laboratories.

The technologies developed so far refer mainly to NIPD of trisomy 21. Nevertheless, the development of NIPD for other common aneuploidies such as those associated with chromosomes 13 and 18 is very close. NGS-based approaches have already been investigated in pilot studies to address the issue $[92,94]$. In addition, the MeDIP realtime qPCR-based approach has already taken into account the need for the development of NIPD of aneuploidies associated with chromosomes 13, 18, $\mathrm{X}$ and $\mathrm{Y}$ through the identification of DMRs located on these chromosomes [98]. Developers predict that NIPD will be applied to monogenic diseases and complete fetal genome mapping within the next 10 years [119]. Furthermore, we speculate that NIPD will replace the existing invasive methods within the next 5 years, eliminating the risk of fetal loss.

\section{Abbreviations}

cffDNA, cell free fetal DNA; CVS, chorionic villi sampling; DANSR, digital analysis of selected regions; DMR, differentially methylated region; FACS, fluorescence-activated cell sorting; ffDNA, free fetal DNA; FISH, fluorescence in situ hybridization; LDT, laboratory-developed test; MACS, magnetic-activated cell sorting; MeDIP, methylated DNA immunoprecipitation; MPSS, massively parallel shotgun sequencing; $M S$, mass spectroscopy; NGS, next-generation sequencing; NIPD, non-invasive prenatal diagnosis; NRBC, nucleated red blood cell; PCR, polymerase chain reaction; $\mathrm{PPCR}$, quantitative polymerase chain reaction; $R C D$, relative chromosome dosage; $S N P$, single nucleotide polymorphism.

\section{Competing interests}

The authors have filed a PCT patent application for the NIPD MeDIP real time qPCR based approach (PCT Patent Application No. PCT/1B2011/000217). The MeDIP real time qPCR study performed by our team was funded by the SAFE Network of Excellence European Commission Funded 6th Framework Package Project Number: LSHB-CT-2004-503243, the Cyprus Institute of Neurology and Genetics and NIPD Genetics Ltd.

\section{Author details}

'The Cyprus Institute of Neurology and Genetics, PO Box 23462, 1683, Nicosia, Cyprus. ${ }^{2 N I P D}$ Genetics Ltd, PO Box 27954, 2434, Nicosia, Cyprus.

Published: 28 May 2012

\section{References}

1. Hulten MA, Dhanjal S, Pertl B: Rapid and simple prenatal diagnosis of common chromosome disorders: advantages and disadvantages of the molecular methods FISH and QF-PCR. Reproduction 2003, 126:279-97.

2. Grimshaw G, Szczepura A, Hultén M, MacDonald F, Nevin N, Sutton F, Dhanjal S: Evaluation of molecular tests for prenatal diagnosis of chromosome abnormalities. Health Technol Assess 2003, 7:1-146.

3. Divane A, Carter NP, Spathas DH, Ferguson-Smith MA: Rapid prenatal diagnosis of aneuploidy from uncultured amniotic fluid cells using fivecolour fluorescence in situ hybridization. Prenat Diagn 1994, 14:1061-1069.

4. Driscoll DA, Gross S: Clinical practice. Prenatal screening for aneuploidy. NEngl J Med 2009, 360:2556-2562.

5. Hassold T, Abruzzo M, Adkins K, Griffin D, Merrill M, Millie E, Saker D, Shen J, Zaragoza M: Human aneuploidy: incidence, origin, and etiology. Environ Mol Mutagen 1996, 28:167-175.

6. Griffiths AJF, Jeffrey H, Suzuki DT, Lewontin RC, Gelbart WM: Chromosome mutation II: changes in chromosome number. In An Introduction to Genetic Analysis. 7th edition. Edited by Griffith AJF, Miller JH, Suzuki DT, Lewontin RC, Gelbart WM. New York: WH Freeman and Company; 2000.

7. Valenti C, Schutta EJ, Kehaty T: Prenatal diagnosis of Down's syndrome Lancet 1968, 2:220.

8. Wapner RJ: Invasive prenatal diagnostic techniques. Semin Perinato/ 2005, 29:401-404

9. Chachkin CJ: What potent blood: non-invasive prenatal genetic diagnosis and the transformation of modern prenatal care. Am J Law Med 2007, 33:9-53.

10. Caughey $A B$, Hopkins LM, Norton ME: Chorionic villus sampling compared 
with amniocentesis and the difference in the rate of pregnancy loss. Obstet Gynecol 2006, 108:612-616.

11. Mujezinovic F, Alfirevic Z: Procedure-related complications of amniocentesis and chorionic villous sampling: a systematic review. Obstet Gynecol 2007, 110:687-694

12. Lo YM, Corbetta N, Chamberlain PF, Rai V, Sargent IL, Redman CW, Wainscoat JS: Presence of fetal DNA in maternal plasma and serum. Lancet 1997 , 350:485-487.

13. Bianchi DW, Avent ND, Costa JM, van der Schoot CE: Noninvasive prenatal diagnosis of fetal Rhesus D: ready for Prime(r) Time. Obstet Gynecol 2005, 106:841-844.

14. Lo YM, Hjelm NM, Fidler C, Sargent IL, Murphy MF, Chamberlain PF, Poon PM Redman CW, Wainscoat JS: Prenatal diagnosis of fetal RhD status by molecular analysis of maternal plasma. N Eng/ J Med 1998, 339:1734-1738.

15. Lo YM, Tein MS, Lau TK, Haines CJ, Leung TN, Poon PM, Wainscoat JS, Johnson PJ, Chang AM, Hjelm NM: Quantitative analysis of fetal DNA in maternal plasma and serum: implications for noninvasive prenatal diagnosis. Am $J$ Hum Genet 1998, 62:768-775.

16. Lun FM, Chiu RW, Allen Chan KC, Yeung Leung T, Kin Lau T, Dennis Lo YM: Microfluidics digital PCR reveals a higher than expected fraction of fetal DNA in maternal plasma. Clin Chem 2008, 54:1664-1672.

17. Chan KC, Zhang J, Hui AB, Wong N, Lau TK, Leung TN, Lo KW, Huang DW, LO YM: Size distributions of maternal and fetal DNA in maternal plasma. Clin Chem 2004, 50:88-92.

18. Poon LL, Leung TN, Lau TK, Chow KC, Lo YM: Differential DNA methylation between fetus and mother as a strategy for detecting fetal DNA in maternal plasma. Clin Chem 2002, 48:35-41.

19. Chiu RW, Chan KC, Gao Y, Lau VY, Zheng W, Leung TY, Foo CH, Xie B, Tsui NB, Lun FM, Zee BC, Lau TK, Cantor CR, Lo YM: Noninvasive prenatal diagnosis of fetal chromosomal aneuploidy by massively parallel genomic sequencing of DNA in maternal plasma. Proc Natl Acad Sci U S A 2008, 105:20458-20463.

20. Fan HC, Blumenfeld YJ, Chitkara U, Hudgins L, Quake SR: Noninvasive diagnosis of fetal aneuploidy by shotgun sequencing DNA from maternal blood. Proc Natl Acad Sci U S A 2008, 105:16266-16271.

21. Chim SS, Tong YK, Chiu RW, Lau TK, Leung TN, Chan LY, Oudejans CB, Ding C, Lo YM: Detection of the placental epigenetic signature of the maspin gene in maternal plasma. Proc Natl Acad Sci U S A 2005, 102:14753-14758.

22. Old RW, Crea F, Puszyk W, Hulten MA: Candidate epigenetic biomarkers for non-invasive prenatal diagnosis of Down syndrome. Reprod Biomed Online 2007, 15:227-235.

23. Chim SS, Jin S, Lee TY, Lun FM, Lee WS, Chan LY, Jin Y, Yang N, Tong YK, Leung TY, Lau TK, Ding C, Chiu RW, Lo YM: Systematic search for placental DNAmethylation markers on chromosome 21: toward a maternal plasmabased epigenetic test for fetal trisomy 21. Clin Chem 2008, 54:500-511.

24. Ng EK, Tsui NB, Lau TK, Leung TN, Chiu RW, Panesar NS, Lit LC, Chan KW, Lo YM: mRNA of placental origin is readily detectable in maternal plasma. Proc Natl Acad Sci U S A 2003, 100:4748-4753.

25. Avent ND, Plummer ZE, Madgett TE, Maddocks DG, Soothill PW: Postgenomics studies and their application to non-invasive prenatal diagnosis. Semin Fetal Neonatal Med 2008, 13:91-98.

26. Hawes CS, Suskin HA, Petropoulos A, Latham SE, Mueller UW: A morphologic study of trophoblast isolated from peripheral blood of pregnant women. Am J Obstet Gynecol 1994, 170:1297-1300.

27. Schueler PA, Yamanishi DT, Pearson J, Lee Y, Wu X, Hashima S, Madlansacay MR, Cain CA, Collarini EJ, Foltz L, Mahoney W: Inconsistency of fetal trophoblast cells in first trimester maternal peripheral blood prevents non-invasive fetal testing using this cell target. Placenta 2001, 22:702-715.

28. Ciaranfi A, Curchod A, Odartchenko N: [Post-partum survival of fetal lymphocytes in the maternal blood]. Schweiz Med Wochenschr 1977 107:134-138.

29. Pearson HA: Life-span of the fetal red blood cell. J Pediatr 1967, 70:166-171

30. Bianchi DW, Flint AF, Pizzimenti MF, Knoll JH, Latt SA: Isolation of fetal DNA from nucleated erythrocytes in maternal blood. Proc Natl Acad SciU S A 1990, 87:3279-3283.

31. Sohda S, Arinami T, Hamada H, Nakauchi H, Hamaguchi H, Kubo T: The proportion of fetal nucleated red blood cells in maternal blood: estimation by FACS analysis. Prenat Diagn 1997, 17:743-752.

32. Jansen MW, von Lindern M, Beug $H$, Brandenburg $H$, Wildschut $H I$, Wladimiroff JW, In't Veld PA: The use of in vitro expanded erythroid cells in a model system for the isolation of fetal cells from maternal blood. Prenat Diagn 1999, 19:323-329.
33. Krabchi K, Gros-Louis F, Yan J, Bronsard M, Masse J, Forest JC, Drouin R: Quantification of all fetal nucleated cells in maternal blood between the 18th and 22nd weeks of pregnancy using molecular cytogenetic techniques. Clin Genet 2001, 60:145-150.

34. Troeger C, Holzgreve W, Hahn S: A comparison of different density gradients and antibodies for enrichment of fetal erythroblasts by MACS. Prenat Diagn 1999, 19:521-526.

35. Hahn S, Garvin AM, Di Naro E, Holzgreve W: Allele drop-out can occur in alleles differing by a single nucleotide and is not alleviated by preamplification or minor template increments. Genet Test 1998, 2:351-355.

36. Sekizawa A, Samura O, Zhen DK, Falco V, Farina A, Bianchi DW: Apoptosis in fetal nucleated erythrocytes circulating in maternal blood. Prenat Diagn 2000, 20:886-889.

37. Hahn S, Zhong XY, Holzgreve W: Recent progress in non-invasive prenatal diagnosis. Semin Fetal Neonatal Med 2008, 13:57-62.

38. Prieto B, Alonso R, Paz A, Candenas M, Venta R, Ladenson JH, Alvarez FV: Optimization of nucleated red blood cell (NRBC) recovery from maternal blood collected using both layers of a double density gradient. Prenat Diagn 2001, 21:187-193.

39. Price JO, Elias S, Wachtel SS, Klinger K, Dockter M, Tharapel A, Shulman LP, Phillips OP, Meyers CM, Shook D: Prenatal diagnosis with fetal cells isolated from maternal blood by multiparameter flow cytometry. Am J Obstet Gynecol 1991, 165:1731-1737.

40. Ganshirt-Ahlert D, Burschyk M, Garritsen HS, Helmer L, Miny P, Horst J, Schneider HP, Holzgreve W: Magnetic cell sorting and the transferrin receptor as potential means of prenatal diagnosis from maternal blood. Am J Obstet Gynecol 1992, 166:1350-1355.

41. Busch J, Huber P, Pfluger E, Miltenyi S, Holtz J, Radbruch A: Enrichment of fetal cells from maternal blood by high gradient magnetic cell sorting (double MACS) for PCR-based genetic analysis. Prenat Diagn 1994 14:1129-1140.

42. Wachtel SS, Sammons D, Manley M, Wachtel G, Twitty G, Utermohlen J, Phillips OP, Shulman LP, Taron DJ, Muller UR, Koeppen P, Ruffalo TM, Addis K, Porreco R, Murata-Collins J, Parker NB, McGavran L: Fetal cells in maternal blood: recovery by charge flow separation. Hum Genet 1996, 98:162-166.

43. Busch J, Huber P, Holtz J, Pfluger E, Radbruch A: Simple and fast "doubleMACS" sorting of fetal erythroblasts from maternal blood for PCR-based paternity analysis. Ann N Y Acad Sci 1994, 731:144-146.

44. Bianchi DW, Simpson JL, Jackson LG, Elias S, Holzgreve W, Evans MI, Dukes KA Sullivan LM, Klinger KW, Bischoff FZ, Hahn S, Johnson KL, Lewis D, Wapner RJ, de la Cruz F: Fetal gender and aneuploidy detection using fetal cells in maternal blood: analysis of NIFTY I data. National Institute of Child Health and Development Fetal Cell Isolation Study. Prenat Diagn 2002, 22:609-615.

45. Bianchi DW, Williams JM, Sullivan LM, Hanson FW, Klinger KW, Shuber AP: PCR quantitation of fetal cells in maternal blood in normal and aneuploid pregnancies. Am J Hum Genet 1997, 61:822-829.

46. Hung EC, Chiu RW, Lo YM: Detection of circulating fetal nucleic acids: a review of methods and applications. J Clin Pathol 2009, 62:308-313.

47. Wright CF, Burton $\mathrm{H}$ : The use of cell-free fetal nucleic acids in maternal blood for non-invasive prenatal diagnosis. Hum Reprod Update 2009, 15:139-151.

48. Bischoff FZ, Sinacori MK, Dang DD, Marquez-Do D, Horne C, Lewis DE, Simpson JL: Cell-free fetal DNA and intact fetal cells in maternal blood circulation: implications for first and second trimester non-invasive prenatal diagnosis. Hum Reprod Update 2002, 8:493-500.

49. Adinolfi M, Davies A, Sharif S, Soothill P, Rodeck C: Detection of trisomy 18 and $Y$-derived sequences in fetal nucleated cells obtained by transcervical flushing. Lancet 1993, 342:403-404.

50. Loke YW, King A, Burrows T, Gardner L, Bowen M, Hiby S, Howlett S, Holmes N, Jacobs D: Evaluation of trophoblast HLA-G antigen with a specific monoclonal antibody. Tissue Antigens 1997, 50:135-146.

51. Bulmer JN, Cioni R, Bussani C, Cirigliano V, Sole F, Costa C, Garcia P, Adinolfi M: HLA-G positive trophoblastic cells in transcervical samples and their isolation and analysis by laser microdissection and QF-PCR. Prenat Diagn 2003, 23:34-39.

52. Sifakis S, Ghatpande S, Seppo A, Kilpatrick MW, Tafas T, Tsipouras P, Fejgin M, Amiel A: Prenatal diagnosis of trisomy 21 through detection of trophoblasts in cervical smears. Early Hum Dev 2010, 86:311-313.

53. Mandel P, Métals P: Les acides nucléiques du sanguine chez l'homme. CRAcad Sci Paris 1948, 142:241-243.

54. Sekizawa A, Kondo T, Iwasaki M, Watanabe A, Jimbo M, Saito H, Okai T: 
Accuracy of fetal gender determination by analysis of DNA in maternal plasma. Clin Chem 2001, 47:1856-1858.

55. Birch L, English CA, O'Donoghue K, Barigye O, Fisk NM, Keer JT: Accurate and robust quantification of circulating fetal and total DNA in maternal plasma from 5 to 41 weeks of gestation. Clin Chem 2005, 51:312-320.

56. Honda H, Miharu N, Ohashi Y, Samura O, Kinutani M, Hara T, Ohama K: Fetal gender determination in early pregnancy through qualitative and quantitative analysis of fetal DNA in maternal serum. Hum Genet 2002, 110:75-79.

57. Papasavva T, Kalikas I, Kyrri A, Kleanthous M: Arrayed primer extension for the noninvasive prenatal diagnosis of beta-thalassemia based on detection of single nucleotide polymorphisms. Ann N Y Acad Sci 2008, 1137:302-308

58. Papasavva T, Kalakoutis G, Kalikas I, Neokli E, Papacharalambous S, Kyrri A, Kleanthous M: Noninvasive prenatal diagnostic assay for the detection of beta-thalassemia. Ann N Y Acad Sci 2006, 1075:148-153.

59. Fucharoen G, Tungwiwat W, Ratanasiri T, Sanchaisuriya K, Fucharoen S: Prenatal detection of fetal hemoglobin E gene from maternal plasma. Prenat Diagn 2003, 23:393-396.

60. Gonzalez-Gonzalez MC, Garcia-Hoyos M, Truijllo MJ, Rodriguez de Alba M, Lorda-Sanchez I, Diaz-Recasens J, Gallardo E, Ayuso C, Ramos C: Prenatal detection of a cystic fibrosis mutation in fetal DNA from maternal plasma. Prenat Diagn 2002, 22:946-948.

61. Saito H, Sekizawa A, Morimoto T, Suzuki M, Yanaihara T: Prenatal DNA diagnosis of a single-gene disorder from maternal plasma. Lancet 2000 356:1170.

62. Ding C, Chiu RW, Lau TK, Leung TN, Chan LC, Chan AY, Charoenkwan P, Ng IS, Law HY, Ma ES, Xu X, Wanapirak C, Sanguansermsri T, Liao C, Ai MA, Chui DH, Cantor CR, Lo YM: MS analysis of single-nucleotide differences in circulating nucleic acids: Application to noninvasive prenatal diagnosis. Proc Natl Acad SciU S A 2004, 101:10762-10767.

63. LiY, Hahn D, Wenzel F, Holzgreve W, Hahn S: Detection of SNPs in the plasma of pregnant women and in the urine of kidney transplant recipients by mass spectrometry. Ann N Y Acad Sci 2006, 1075:144-147.

64. Tang K, Fu DJ, Julien D, Braun A, Cantor CR, Koster H: Chip-based genotyping by mass spectrometry. Proc Natl Acad Sci U S A 1999, 96:10016-10020

65. Li Y, Zimmermann B, Rusterholz C, Kang A, Holzgreve W, Hahn S: Size separation of circulatory DNA in maternal plasma permits ready detection of fetal DNA polymorphisms. Clin Chem 2004, 50:1002-1011.

66. Lo YM, Chiu RW: Noninvasive prenatal diagnosis of fetal chromosomal aneuploidies by maternal plasma nucleic acid analysis. Clin Chem 2008, 54:461-466.

67. Dhallan R, Au WC, Mattagajasingh S, Emche S, Bayliss P, Damewood M, Cronin M, Chou V, Mohr M: Methods to increase the percentage of free fetal DNA recovered from the maternal circulation. JAMA 2004, 291:1114-1119.

68. Dhallan R, Guo X, Emche S, Damewood M, Bayliss P, Cronin M, Barry J, Betz J, Franz K, Gold K, Vallecillo B, Varney J: A non-invasive test for prenatal diagnosis based on fetal DNA present in maternal blood: a preliminary study. Lancet 2007, 369:474-481.

69. Chinnapapagari SK, Holzgreve W, Lapaire O, Zimmermann B, Hahn S: Treatment of maternal blood samples with formaldehyde does not alter the proportion of circulatory fetal nucleic acids (DNA and mRNA) in maternal plasma. Clin Chem 2005, 51:652-655.

70. Chung GT, Chiu RW, Chan KC, Lau TK, Leung TN, Lo YM: Lack of dramatic enrichment of fetal DNA in maternal plasma by formaldehyde treatment. Clin Chem 2005, 51:655-658.

71. Weber M, Davies JJ, Wittig D, Oakeley EJ, Haase M, Lam WL, Schubeler D: Chromosome-wide and promoter-specific analyses identify sites of differential DNA methylation in normal and transformed human cells. Nat Genet 2005, 37:853-862.

72. Jones PA, Baylin SB: The epigenomics of cancer. Cell 2007, 128:683-692.

73. Esteller M, Sanchez-Cespedes M, Rosell R, Sidransky D, Baylin SB, Herman JG Detection of aberrant promoter hypermethylation of tumor suppressor genes in serum DNA from non-small cell lung cancer patients. Cancer Res 1999, 59:67-70.

74. Lo YM, Wong IH, Zhang J, Tein MS, Ng MH, Hjelm NM: Quantitative analysis of aberrant p16 methylation using real-time quantitative methylationspecific polymerase chain reaction. Cancer Res 1999, 59:3899-3903.

75. Wong IH, Lo YM, Zhang J, Liew CT, Ng MH, Wong N, Lai PB, Lau WY, Hjelm NM, Johnson PJ: Detection of aberrant p16 methylation in the plasma and serum of liver cancer patients. Cancer Res 1999, 59:71-73.
76. Herman JG, Graff JR, Myohanen S, Nelkin BD, Baylin SB: Methylation-specific PCR: a novel PCR assay for methylation status of $\mathrm{CpG}$ islands. Proc Nat Acad Sci U S A 1996, 93:9821-9826

77. Chiu RW, Chim SS, Wong IH, Wong CS, Lee WS, To KF, Tong JH, Yuen RK, Shum AS, Chan JK, Chan LY, Yuen JW, Tong YK, Weier JF, Ferlatte C, Leung TN, Lau TK, Lo KW, Lo YM: Hypermethylation of RASSF1A in human and rhesus placentas. Am J Pathol 2007, 170:941-950.

78. Tong YK, Chiu RW, Akolekar R, Leung TY, Lau TK, Nicolaides KH, Lo YM: Epigenetic-genetic chromosome dosage approach for fetal trisomy 21 detection using an autosomal genetic reference marker. PLoS One 2010, 5:e15244.

79. Tong YK, Jin S, Chiu RW, Ding C, Chan KC, Leung TY, Yu L, Lau TK, Lo YM: Noninvasive prenatal detection of trisomy 21 by an epigenetic-genetic chromosome-dosage approach. Clin Chem 2010, 56:90-98.

80. Tong YK, Ding C, Chiu RW, Gerovassili A, Chim SS, Leung TY, Leung TN, Lau TK, Nicolaides KH, Lo YM: Noninvasive prenatal detection of fetal trisomy 18 by epigenetic allelic ratio analysis in maternal plasma: Theoretical and empirical considerations. Clin Chem 2006, 52:2194-2202.

81. Grunau C, Clark SJ, Rosenthal A: Bisulfite genomic sequencing: systematic investigation of critical experimental parameters. Nucleic Acids Res 2001, 29:E65-65.

82. Fazzari MJ, Greally JM: Epigenomics: beyond CpG islands. Nat Rev Genet 2004, 5:446-455

83. Eckhardt F, Lewin J, Cortese R, Rakyan VK, Attwood J, Burger M, Burton J, Cox TV, Davies R, Down TA, Haefliger C, Horton R, Howe K, Jackson DK, Kunde J, Koenig C, Liddle J, Niblett D, Otto T, Pettett R, Seemann S, Thompson C, West T, Rogers J, Olek A, Berlin K, Beck S: DNA methylation profiling of human chromosomes 6, 20 and 22. Nat Genet 2006, 38:1378-1385.

84. Rakyan VK, Down TA, Thorne NP, Flicek P, Kulesha E, Graf S, Tomazou EM, Backdahl L, Johnson N, Herberth M, Howe KL, Jackson DK, Miretti MM, Fiegler H, Marioni JC, Birney E, Hubbard TJ, Carter NP, Tavare S, Beck S: An integrated resource for genome-wide identification and analysis of human tissuespecific differentially methylated regions (tDMRs). Genome Res 2008 18:1518-1529.

85. Tsui NB, Chiu RW, Ding C, El-Sheikhah A, Leung TN, Lau TK, Nicolaides KH, Lo YM: Detection of trisomy 21 by quantitative mass spectrometric analysis of single-nucleotide polymorphisms. Clin Chem 2005, 51:2358-2362.

86. Geifman-Holtzman O, Ober Berman J: Prenatal diagnosis: update on invasive versus noninvasive fetal diagnostic testing from maternal blood. Expert Rev Mol Diagn 2008, 8:727-751

87. Bahtiyar MO, Copel JA, Mahoney MJ, Buhimschi IA, Buhimschi CS: Proteomics: a novel methodology to complement prenatal diagnosis of chromosomal abnormalities and inherited human diseases. Am J Perinatol 2007. 24:167-181.

88. Fan HC, Quake SR: Sensitivity of noninvasive prenatal detection of fetal aneuploidy from maternal plasma using shotgun sequencing is limited only by counting statistics. PLoS One 2010, 5:e10439.

89. Chiu RW, Akolekar R, Zheng YW, Leung TY, Sun H, Chan KC, Lun FM, Go AT, Lau ET, To WW, Leung WC, Tang RY, Au-Yeung SK, Lam H, Kung YY, Zhang X, van Vugt JM, Minekawa R, Tang MH, Wang J, Oudejans CB, Lau TK, Nicolaides $\mathrm{KH}$, Lo YM: Non-invasive prenatal assessment of trisomy 21 by multiplexed maternal plasma DNA sequencing: large scale validity study. BMJ 2011, 342: 77401

90. Ehrich M, Deciu C, Zwiefelhofer T, Tynan JA, Cagasan L, Tim R, Lu V, McCullough R, McCarthy E, Nygren AO, Dean J, Tang L, Hutchison D, LuT, Wang H, Angkachatchai V, Oeth P, Cantor CR, Bombard A, van den Boom D: Noninvasive detection of fetal trisomy 21 by sequencing of DNA in maternal blood: a study in a clinical setting. Am J Obstet Gynecol 2011 204:205 e1-11.

91. Palomaki GE, Kloza EM, Lambert-Messerlian GM, Haddow JE, Neveux LM, Ehrich M, van den Boom D, Bombard AT, Deciu C, Grody WW, Nelson SF, Canick JA: DNA sequencing of maternal plasma to detect Down syndrome: an international clinical validation study. Genet Med 2011, 13:913-920.

92. Chen EZ, Chiu RWK, Sun H, Akolekar R, Chan KCA, Leung TY, Jiang P, Zheng YWL, Lun FMF, Chan LYS, Jin Y, Go ATJl, Lau ET, To WWK, Leung WC, Tang RYK, Au-Yeung SKC, Lam H, Kung YY, Zhang $X$, van Vugt JMG, Minekawa R, Tang MHY, Wang J, Oudejans CBM, Lau TK, Nicolaides KH, Lo YMD: Noninvasive prenatal diagnosis of fetal trisomy 18 and trisomy 13 by maternal plasma DNA sequencing. PLOS One 2011, 6:e21791.

93. Sehnert AJ, Rhees B, Comstock D, de Feo E, Heilek G, Burke J, Rava RP: Optimal detection of fetal chromosomal abnormalities by massively 
parallel DNA sequencing of cell-free fetal DNA from maternal blood. Clin Chem 2011, 57:1042-1049.

94. Palomaki GE, Deciu C, Kloza EM, Lambert-Messerlian GM, Haddow JE, Neveux LM, Ehrich M, van den Boom D, Bombard AT, Grody WW, Nelson SF, Canick JA: DNA sequencing of maternal plasma reliably identifies trisomy 18 and trisomy 13 as well as Down syndrome: an international collaborative study. Genet Med 2012, 14:296-305.

95. Sparks AB, Wang ET, Struble CA, Barrett W, Stokowski R, McBride C, Zahn J, Lee K, Shen N, Doshi J, Sun M, Garrison J, Sandler J, Hollemon D, Pattee P, TomitaMitchell A, Mitchell M, Stuelpnagel J, Song K, Oliphant A: Selective analysis of cell-free DNA in maternal blood for evaluation of fetal trisomy. Prenat Diagn 2012, 32:3-9.

96. van den Oever JM, Balkassmi S, Verweij EJ, van Iterson M, Adama van Scheltema PN, Oepkes D, van Lith JM, Hoffer MJ, den Dunnen JT, Bakker E, Boon EM: Single Molecule sequencing of free DNA from maternal plasma for noninvasive trisomy 21 detection. Clin Chem 2012, 58:699-706.

97. Peters D, Chu T, Yatsenko SA, Hendrix N, Hogge WA, Surti U, Bunce K, Dunkel $M$, Shaw P, Rajkovic A: Noninvasive prenatal diagnosis of a fetal microdeletion syndrome. N Engl J Med 2011, 365:1847-1848.

98. Papageorgiou EA, Fiegler H, Rakyan V, Beck S, Hulten M, Lamnissou K, Carter NP, Patsalis PC: Sites of differential DNA methylation between placenta and peripheral blood: molecular markers for noninvasive prenatal diagnosis of aneuploidies. Am J Pathol 2009, 174:1609-1618.

99. Papageorgiou EA, Karagrigoriou A, Tsaliki E, Velissariou V, Carter NP, Patsalis PC: Fetal specific DNA methylation ratio permits non-invasive prenatal diagnosis of trisomy 21. Nat Med 2011, 17:510-513.

100. Poon LL, Leung TN, Lau TK, Lo YM: Presence of fetal RNA in maternal plasma. Clin Chem 2000, 46:1832-1834.

101. Hasselmann DO, Rappl G, Tilgen W, Reinhold U: Extracellular tyrosinase mRNA within apoptotic bodies is protected from degradation in human serum. Clin Chem 2001 47:1488-1489.

102. Ng EK, Tsui NB, Lam NY, Chiu RW, Yu SC, Wong SC, Lo ES, Rainer TH, Johnson PJ, Lo YM: Presence of filterable and nonfilterable mRNA in the plasma of cancer patients and healthy individuals. Clin Chem 2002, 48:1212-1217.

103. Tsui NB, Ng EK, Lo YM: Stability of endogenous and added RNA in blood specimens, serum, and plasma. Clin Chem 2002, 48:1647-1653.

104. Tsui NB, Chim SS, Chiu RW, Lau TK, Ng EK, Leung TN, Tong YK, Chan KC, Lo YM: Systematic micro-array based identification of placental mRNA in maternal plasma: towards non-invasive prenatal gene expression profiling. J Med Genet 2004, 41:461-467.

105. Tsui NB, Lo YM: A microarray approach for systematic identification of placental-derived RNA markers in maternal plasma. Methods Mol Biol 2008,
444:275-289

106. Lo YM, Tsui NB, Chiu RW, Lau TK, Leung TN, Heung MM, Gerovassili A, Jin Y, Nicolaides KH, Cantor CR, Ding C: Plasma placental RNA allelic ratio permits noninvasive prenatal chromosomal aneuploidy detection. Nat Med 2007, 13:218-223.

107. Oudejans CB, Go AT, Visser A, Mulders MA, Westerman BA, Blankenstein MA, van Vugt JM: Detection of chromosome 21-encoded mRNA of placental origin in maternal plasma. Clin Chem 2003, 49:1445-1449.

108. Tsui NB, Akolekar R, Chiu RW, Chow KC, Leung TY, Lau TK, Nicolaides KH, Lo YM: Synergy of total PLAC4 RNA concentration and measurement of the RNA single-nucleotide polymorphism allelic ratio for the noninvasive prenatal detection of trisomy 21. Clin Chem 2010, 56:73-81.

109. Tsui NB, Wong BC, Leung TY, Lau TK, Chiu RW, Lo YM: Non-invasive prenatal detection of fetal trisomy 18 by RNA-SNP allelic ratio analysis using maternal plasma SERPINB2 mRNA: a feasibility study. Prenat Diagn 2009, 29:1031-1037.

110. Lo YM, Lun FM, Chan KC, Tsui NB, Chong KC, Lau TK, Leung TY, Zee BC, Cantor CR, Chiu RW: Digital PCR for the molecular detection of fetal chromosomal aneuploidy. Proc Natl Acad Sci U S A 2007, 104:13116-13121.

111. Fan HC, Quake SR: Detection of aneuploidy with digital polymerase chain reaction. Anal Chem 2007, 79:7576-7579.

112. Vogelstein B, Kinzler KW: Digital PCR. Proc Natl Acad Sci U S A 1999 96:9236-9241

113. SEQUENOM, Inc. [http://www.sequenom.com]

114. Aria Diagnostics, Inc. [http://www.ariadx.com]

115. Verinata Health, Inc. [http://www.verinata.com]

116. Bianchi DW, Platt LD, Goldberg JD, Abuhamad AZ, Sehnert AJ, Rava RP. Genome-wide fetal aneuploidy detection by maternal plasma DNA sequencing. Obstet Gynecol 2012, 119:890-901.

117. NIPD Genetics Ltd [http://www.nipd.com]

118. Whiting P, Rutjes AW, Reitsma JB, Bossuyt PM, Kleijnen J: The development of QUADAS: a tool for the quality assessment of studies of diagnostic accuracy included in systematic reviews. BMC Med Res Methodol 2003, 3:25.

119. Lo YM: Noninvasive prenatal diagnosis in 2020. Prenat Diagn 2010, 30:702-703.

doi:10.1186/gm345

Cite this article as: Papageorgiou EA, Patsalis PC: Non-invasive prenatal diagnosis of aneuploidies: new technologies and clinical applications.

Genome Medicine 2012, 4:46. 